\title{
Factors Associated with Vulnerability to HIV and Sexually Transmitted Infections among Street Children in Selected Towns of Ethiopia, 2016
}

\author{
Ayana Chimdessa ${ }^{1}$, Oladapo Olayemi², Onoja Mathew Akpa ${ }^{2}$ \\ ${ }^{1}$ College of Health Sciences, Debre Berhan University, Debre Berhan, Ethiopia \\ ${ }^{2}$ Faculty of Public Health, College of Medicine University of Ibadan, Ibadan, Nigeria \\ Email: ayanayoom@gmail.com, oladapo.olayemi@yahoo.com,onojamatthew@gmail.com
}

How to cite this paper: Chimdessa, A., Olayemi, O. and Akpa, O.M. (2017) Factors Associated with Vulnerability to HIV and Sexually Transmitted Infections among Street Children in Selected Towns of Ethiopia, 2016. World Journal of AIDS, 7 , 230-238.

https://doi.org/10.4236/wja.2017.73019

Received: July 28, 2017

Accepted: September 27, 2017

Published: September 30, 2017

Copyright $\odot 2017$ by authors and Scientific Research Publishing Inc. This work is licensed under the Creative Commons Attribution International License (CC BY 4.0).

http://creativecommons.org/licenses/by/4.0/

\section{(c) (i) Open Access}

\begin{abstract}
Background: The problem of street children is becoming a world crosscutting issue since these children exist in every part of the world and become a worldwide problem. Objective: To assess factors associated with vulnerability to STIs and HIV/AIDS among street children in selected towns of Ethiopia. Methodology: Community-based cross-sectional descriptive study design was used on the three selected towns of Ethiopia from June-September, 2016. A total of 360 street children were selected, using snow ball sampling technique. Data were collected using pre-tested interviewer-administered questionnaire. Logistic regression was used to analyze the data. Results: A total of $360(97.8 \%)$ respondents were included in this study. Among them, $167(46.4 \%)$ of them had practiced sexual intercourse and out of these, 137 (82\%) had started having sex at the age of 16 years old. Out of these, 61 $(36.53 \%)$ of them started to get daily basic needs whereas $54(32.3 \%)$ of them were forcefully raped on the street. Only 53 (59.6\%) had used condom consistently and $83(49.7 \%)$ had conducted survival sex within the last 12 months. Children on the street or chewing khat or consumption of alcohol had more vulnerability to STIs and HIV about 2.532 (1.57 - 4.08), 2.32 (1.11 - 4.80), 4.18 (2.31 - 7.55) times respectively. But those enrolled in school were about $0.40(0.25,0.64)$ less likely vulnerable than their counterparts. Conclusion: Street children are at a higher likelihood of vulnerability to STIs and HIV. Intervention targeted multilevel approach such as re-integration with their family, life skills training, sexuality education, creating income-generating activities and information education about STIs and HIV should be considered.
\end{abstract}




\section{Keywords}

Street Children, Vulnerability to STIs and HIV/AIDs, Ethiopia

\section{Introduction}

The problem of street children is becoming a world crosscutting issue since these children exist in every part of the world and become a worldwide problem [1]. Even though counting street children is impossible, the number of them sometimes dramatically increases because of various reasons such as poverty, AIDS pandemic, internal tribe conflict and rapid urbanization. These victims drift to live on street where they are exposed to violation, physical or sexual abuse and exploitation which make them prone to STIs and HIV/AIDS [2]. Recent information shows that the number of street children is estimated to be 150 million [3]. According to recent reports in Ethiopia, over 4 million children are anticipated to live under particularly difficult circumstances and there are approximately 500,000 - 700,000 street children in the country [4] [5].

In Ethiopia, HIV/AIDS is a leading cause of orphanhood. According to PEPFAR report of 2012, there were an estimated 5.4 million orphans, of this 855,720 were orphaned due to AIDS and they are left vulnerable [6] [7]. Orphaned and vulnerable street children are also far more likely to move from being affected by the virus to becoming infected and facing other risks. The prevalence of HIV and STIs among street children greatly exceeds that of general children's population [5] [8] [9]. The prevalence of ill health practices, different forms of abuses and sexually transmitted diseases have been found to be higher among street children as compared to children living at home [10] [11]. Understanding the magnitude of vulnerability of street children to STIs and HIV/AIDS and its determinant factors were the aim of this research. Identifying the determinant factors was pivotal to address the needs of street children and to mitigate the negative outcomes for this underprivileged group. However, there is scantiness of information in this regard in Ethiopia. Therefore, the purpose of this study is to investigate factors associated with street children vulnerability to STIs and HIV. From these results it could be provided that direction for designing targeted HIV/AIDS and STIs intervention/prevention for street children in selected towns of Ethiopia.

\section{Methods and Materials}

The study was conducted in three towns of Ethiopia, namely, Addis Ababa, Adama and Hawassa, which are populated and industrialized areas where most street children drift to. Community-based cross-sectional descriptive study design was used in this study. All street children (both children on the street and children off the street) who are between 10 - 18 years of age were recruited by snow ball sampling technique. The sample size was determined by the previous 
study prevalence of STIs and HIV among street children with $31.4 \%$ and $95 \%$ confidence interval, 5\% margin of error and 10\% allowance of non-response rate. Based on this, the calculated sample size was 368 . Then the sample size was proportionately allocated based on the estimated number of street children in the three selected towns. On this basis, 20 were taken from Adama, 25 from Hawassa and 323 from Addis Ababa. A close-ended structured questionnaire was used for data collection. The questionnaire was adapted from previous literatures and other questions were extracted from standardized questionnaires. The questionnaire was prepared in English and then translated by formal translators into local language (Amharic) then back to English to check for consistency of meaning. Finally, the local language version was used for data collection. Respondents who were initiated into early sexual intercourse were considered as vulnerable to STIs and HIV.

Data were collected by 10 BSC nurses and two trained supervisors facilitated data collection. For all data collectors and supervisors, three days of intensive training was given on the objective, procedure and content of the study.

In this study Children off the street are those who are working or begging on the street but living with their parents or visiting their parents regularly. Children on the street-these children live and work on street without any kind of control or assistance from parents or relatives. Both economically and socially engaged in street life.

The questionnaire was pre-tested to assess for clarity and sensitiveness of questions and understanding of study subjects at Ambo town, Oromia region on $5 \%$ of sample size. Based on the pre-test result, some modifications were done. Data were checked for completeness by principal investigator of the study on a daily basis.

Data were first interred to Epi Info 7 and exported to IBM SPSS statics version 20.0 to clean and analyze data. Frequencies, proportions, mean and summary statics were used to describe parameters investigated. Association between dependent and independent variables were assessed and presented, using odd ratios and confidence intervals. Logistic regressions were done to control for possible confounders.

Ethical clearance for the study was received from both University of Ibadan, Nigeria and Ethiopian Public Health Institute. A formal letter was written to all authorities and permission was secured at all levels. Since the study subjects were younger than 18 years written assent was taken from study subjects and consent was taken from care givers or guardians after explaining the purpose and procedure of the study. Participation in the study was voluntary and information collected kept strictly confidential.

\section{Results}

A total of 368 children on the street and children off the street were interviewed and $360(97.83 \%)$ respondents were included in the analysis. Eight respondents 
were excluded from the analysis for a gross incompleteness.

\section{Socio-Demographic Characteristics}

As it is shown in Table 1, 266 (73.9\%) of respondents were male and the mean age of respondents was $15 \pm 2.1$ years with a minimum age of 10 years and a maximum age of 18 years. Out of the total respondents, $222(61.7 \%)$ of them were children on the street and 138 (38.3\%) of them were children off the street. Of the total respondents, 99 (27.5\%) were from Oromo and 94 (26.1\%) of them were from Amhara tribe. Over all 207 (57.5\%) respondents were orthodox and 73 (20.3\%) were protestant followers. Currently, a high proportion of 220 (61.1\%) of street children were not in school or had discontinued their education. A majority of 260 (72.2\%) of the street children highly participate in hard work while 44 (12.2\%) of street children participate in survival sex.

Table 1. Socio-demographic characteristics of street children in selected towns of Ethiopia, $2016(n=360)$.

\begin{tabular}{|c|c|c|}
\hline \multirow{2}{*}{ Characteristics } & \multicolumn{2}{|c|}{ Frequency } \\
\hline & Number & $\%$ \\
\hline \multicolumn{3}{|l|}{ Sex } \\
\hline Male & 266 & 73.9 \\
\hline Female & 94 & 26.1 \\
\hline \multicolumn{3}{|l|}{ Age $($ mean $15 \pm 2.1)$} \\
\hline $10-14$ years old & 153 & 42.5 \\
\hline $15-18$ years old & 207 & 57.5 \\
\hline \multicolumn{3}{|l|}{ Ethnicity } \\
\hline Oromo & 99 & 27.5 \\
\hline Amhara & 94 & 26.1 \\
\hline Tigre & 18 & 5.0 \\
\hline Gurage & 28 & 7.8 \\
\hline Wolayita & 71 & 19.7 \\
\hline Sidama & 39 & 10.8 \\
\hline Others & 11 & 3.1 \\
\hline \multicolumn{3}{|l|}{ Religion } \\
\hline Orthodox & 207 & 57.5 \\
\hline Protestant & 73 & 20.3 \\
\hline Catholic & 19 & 5.3 \\
\hline Muslim & 54 & 15 \\
\hline Others & 7 & 1.9 \\
\hline \multicolumn{3}{|l|}{ Educational status } \\
\hline Never attend school & 81 & 22.5 \\
\hline Grade 1 - 6 & 209 & 58.1 \\
\hline Grade 7 - 8 & 46 & 12.8 \\
\hline Grade $9-10$ & 23 & 6.4 \\
\hline Grade $11-12$ & 1 & 0.3 \\
\hline \multicolumn{3}{|l|}{ Category of street children } \\
\hline Children on the street & 222 & 61.7 \\
\hline Children off the street & 138 & 38.3 \\
\hline
\end{tabular}




\section{Vulnerability of Street Children to STIs and HIV/AIDS}

Sexual relationships among the study subjects were rampant. Out of the total respondents, 167 (46.4\%) of them had practiced sexual intercourse and of this, 137 (82\%) had started sexual intercourse before the age of 16 years old. They pointed the reasons to start sex early, 61 (36.53\%) of respondents started to get daily basic needs, whereas, 54 (32.3\%) of them were forcefully raped on the street while $29(17.4 \%)$ for social connection in their community. Of those who ever had sex, 44 (26.3\%) had sex with commercial sex workers. More than half, $89(53.3 \%)$ of those who had started sexual intercourse used any method to protect themselves. About, 53 (59.6\%) used condom, 17 (19.1\%) douching and 12 (13.5\%) withdrawal non protection method. In contrast 78 (46.7\%) of respondents did not use any protection method. The reason for this were, 23 (29.5\%) their partner did not agree to use whereas 19 (24.4\%) did not have money to buy any protection methods.

On their first sexual exposure, 45 (26.9\%) under the influence of alcohol alongside their partners and 32 (19.2\%) of children were under the influence of alcohol. About 83 (49.7\%) of respondents conducted survival sex within the last 12 months. Of all those who practiced sex, $70 \%$ had a history of multiple sexual partners in the last 12 months. Half of the sexually active respondents 79 (47.3\%) practiced anal sex with two or more partners during their life time on the street. All over, 89 (24.7\%) of respondents reported, they had been affected by one or more of STIs symptoms.

\section{Factors Associated with Street Children's Vulnerability to STIs and HIV/AIDS}

This study shows that, almost all of the study participants (100\%) had one or more misconceptions about STIs, and HIV/AIDs ways of transmission and prevention. Of the total respondents, 89 (24.7\%) said that mosquito bites can transmit HIV/AIDS from person to person while 208 (57.8\%) noted that a woman with HIV/AIDs can transmit the virus to her newborn infant through breastfeeding. About, 130 (36.1\%) of the respondents did not perceive as they were at risk of contracting STIs and HIV/AIDS.

Substance use was relatively high among the study subjects. As it is shown in Table 2, overall, 151 (41.9\%) respondents chewed khat, 161 (44.7\%) have smoked, chewed or sniffed any tobacco products and $162(45 \%)$ of the study subjects have drunk alcohol beverages on a daily basis.

\section{Predictors of Vulnerability in Street Children to STIs and HIV/AIDS}

The multivariate analysis in Table 3 shows that, children on the street were about $2.53(1.57,4.08)$ times more likely vulnerable to STIs and HIV than children off the street. Street children who were enrolled in school were about 0.400 $(0.249,0.644)$ less likely vulnerable to STIs and HIV than those who were not enrolled in school. Street children who have been given something for the sake 
Table 2. Substance use behavior of street children in selected towns of Ethiopia, $2016(\mathrm{n}=360)$.

\begin{tabular}{|c|c|c|}
\hline \multirow[t]{2}{*}{ Characteristics } & \multicolumn{2}{|c|}{ Frequency } \\
\hline & Number & $\%$ \\
\hline \multicolumn{3}{|c|}{ Have you ever chewed khat } \\
\hline Yes & 151 & 41.9 \\
\hline No & 209 & 58.1 \\
\hline \multicolumn{3}{|c|}{ Have you ever smoked chewed or sniffed any tobacco product } \\
\hline Yes & 161 & 44.7 \\
\hline No & 199 & 55.3 \\
\hline \multicolumn{3}{|c|}{ Have you ever drunk any alcoholic beverage } \\
\hline Yes & 162 & 45 \\
\hline No & 198 & 55 \\
\hline \multicolumn{3}{|c|}{ Have you ever taken glue } \\
\hline Yes & 92 & 25.6 \\
\hline No & 268 & 74.4 \\
\hline \multicolumn{3}{|c|}{ Have you ever taken any cannabis } \\
\hline Yes & 60 & 16.7 \\
\hline No & 300 & 83.3 \\
\hline
\end{tabular}

Table 3. Predictors of ever had sex among street children in selected towns of Ethiopia, $2016(\mathrm{n}=360)$.

\begin{tabular}{|c|c|c|c|c|c|c|}
\hline \multirow{2}{*}{ Variables } & \multicolumn{2}{|c|}{ Ever had sex } & \multirow{2}{*}{ COR $(95 \% \mathrm{CI})$} & \multirow{2}{*}{ p-value } & \multirow{2}{*}{ AOR $(95 \% \mathrm{CI})$} & \multirow{2}{*}{$\mathrm{p}$-value } \\
\hline & Yes & No & & & & \\
\hline \multicolumn{7}{|c|}{ Category of street children } \\
\hline On street & $127(57.2 \%)$ & $95(42.8 \%)$ & $3.28(2.08-5.16)$ & $<0.001$ & $2.53(1.57-4.08)$ & $<0.001$ \\
\hline Off street & $40(29 \%)$ & $98(71 \%)$ & 1.00 & & 1.000 & \\
\hline \multicolumn{7}{|c|}{ Current-enrolment in school } \\
\hline Yes & $41(29.3 \%)$ & $99(70.7 \%)$ & 1.00 & $<0.001$ & $0.40(0.25-0.64)$ & $<0.001$ \\
\hline No & $126(57.3 \%)$ & $94(42.7 \%)$ & $3.24(2.06-5.08)$ & & 1.000 & \\
\hline \multicolumn{7}{|c|}{ Forced to have sex } \\
\hline Yes & $79(74.5 \%)$ & $27(25.5 \%)$ & & $<0.001$ & $5.28(3.16-8.82)$ & $<0.001$ \\
\hline No & $88(34.6 \%)$ & $166(65.4 \%)$ & $5.52(3.32-9.17)$ & & 1.000 & \\
\hline \multicolumn{7}{|c|}{ Given something to have sex } \\
\hline Yes & $89(75.4 \%)$ & $29(24.6 \%)$ & $6.45(3.92-10.62)$ & $<0.001$ & $3.34(1.89-5.95)$ & $<0.001$ \\
\hline No & $78(32.2 \%)$ & $164(67.8 \%)$ & 1.00 & & 1.000 & \\
\hline \multicolumn{7}{|c|}{ Ever chewed khat } \\
\hline Yes & $112(74.2 \%)$ & $39(25.8 \%)$ & $8.04(4.99-12.96)$ & $<0.001$ & $2.32(1.11-48)$ & 0.026 \\
\hline No & $55(26.3 \%)$ & $154(73.7 \%)$ & 1.00 & & 1.000 & \\
\hline \multicolumn{7}{|c|}{ Ever drunk any alcoholic beverage } \\
\hline Yes & $121(74.7 \%)$ & $41(25.3 \%)$ & $9.75(6.01-15.82)$ & $<0.001$ & $4.18(2.31-7.55)$ & $<0.001$ \\
\hline No & $46(23.2 \%)$ & $152(76.8 \%)$ & 1.00 & & 1.000 & \\
\hline
\end{tabular}

of sex were about $5.28(3.16$ - 8.82) times more likely susceptible to STIs and HIV than their counterparts.

In multivariate analysis, after controlling socio-demographic factors, alcohol and khat use were independently associated with sexually active respondents. Street children who had ever chewed khat and those who used alcoholic beverage were about $2.32(1.11-4.80)$ and $4.18(2.31$ - 7.55) times more likely vulnerable to STIs and HIV/AIDS than their counterparts respectively. 


\section{Discussion}

The study examined the vulnerability of street children to HIV and STIs. Findings of the study showed that about half of the street children were vulnerable to STIs and HIV. There is widespread sexual intercourse among street children and outsiders. Concurrently, different studies showed that there are rampant sexual activities among street children and with others in the community [3] [5].

In this study, (46.4\%) of street children were proven be involved in sexual intercourse which is lower than the previous study conducted among street children in Democratic Republic of Congo (85.5\%) and Egypt (67\%) [12] [13]. This variation could be due to the difference in the age group of the study subjects, as this study included younger (10 - 18 years old). The other possible explanation for this difference might be that, in this study, children off the street were study subjects. Perhaps, they have to go back home every night, this prevents early sexual initiation.

In this study, (36.53\%) of the study participants started sex to get daily basic needs, whereas, $32.3 \%$ were forceful raped on the street while $17.4 \%$ of participants started for social connection in their community. However, the study conducted in DRC shows that the reason for sexual activity among male is for enjoyment (74.3\%) and female (56.4\%) are influenced by peer pressure [14].

Multiple sexual partners are very common among the study subjects. In the past 12 months, $70 \%$ sexually active street children had sex with two to five partners on the average which is similar to the findings in DCR 69.2\% male and $53.8 \%$ female practiced [15] [16]. In this study about, (47.3\%) respondents had practiced anal sex, in agreement with this finding, a study conducted in Kathmandu and Kenya reported that $39 \%$ of boys and $12 \%$ of the females experienced anal sex [17] [18].

This finding shows, $12.2 \%$ of street children participated in survival sex in the last 12 months. This percentage is lower compared to the study conducted in Kenya, where 53\% male and 64\% female participated in begging and survival sex. This difference may be due to the inclusion of the children off the street who go back home for the night and who got support from different institutions, hence delaying sexual initiation. This report showed that $24.7 \%$ of participants have experienced one or more of STIs symptoms which is comparable with the study conducted in other part of Ethiopia, where $24.8 \%$ had a history of STIs [16] [19].

This study revealed that, 59.6\% had used condom whereas, $19.1 \%$ and $13.5 \%$ of them had used protection methods like douching and withdrawal respectively. However, $46.7 \%$ of them did not use any methods of protection. This is similar with the study conducted in different Sub-Saharan countries [16] [19] [20].

This finding showed that about, $41.9 \%$ of respondents reported to have ever chewed khat and $44.7 \%$ ever smoked, chewed or sniffed any tobacco products. The study conducted in Egypt and Rwanda showed higher percentage [13] [21], this variation may possibly be due to the availability of the drugs and the study area can also be a factor. 


\section{Conclusions}

Findings in this study showed that a high number of street children had initiated early sexual intercourse which possibly facilitated an increase in the number of sexual partners in their life and made them highly vulnerable to STIs and HIV/AIDS and all other related health risks.

This study revealed that $82 \%$ of the study participants had started having sex before the age of 16 years. The participants reported that this early sexual initiation was due to their need of good items and forceful rape on the street. Initiating sexual intercourse for social connection on the street was common, especially for the newcomers among the street children. Even if they were practicing sexual intercourse with multiple sexual partners, the probability of condom use was vested in the interest of their partners.

Substance use and lack of knowledge about STIs and HIV/AIDS ways of transmission and prevention were found to be the factors for vulnerability among Ethiopian street children.

Interventions targeted multilevel approach, such as re-integration with their family, life skills training, sexuality education, creation of income-generating activities and information education about STIs and HIV should be considered.

\section{Competing Interest}

The authors declared that there is no competing interest.

\section{Authors' Contribution}

All authors, Ayana Chimdessa, Oladepo Olayemi and Onoja Matthew Akpa, participated from inception of the idea to the design, analysis and interpretation of the results. All authors have read and approved the final manuscript.

\section{Acknowledgements}

The authors would like to wholeheartedly thank the study participants who devoted their time to participate in the study and contribute their valuable responses.

\section{References}

[1] Demelash, H. and Adamu, A. (2013) Sexual and Reproductive Health Status of Street Children in Addis Ababa. Journal of Sexually Transmitted Diseases, 2013, Article ID: 524076.

[2] SMaC, S. (2008) Street Children's Sexual Realities and the Association for Promoting Social Action.

[3] Mandalazi, P., Banda, C. and Umar, E. (2013) Street Children's Vulnerability to HIV and Sexually Transmitted Infections in Malawian Cities. Malawi Medical Journal, 25, 1-4.

[4] UNICEF (2010) Annual Report for Ethiopia, Addis Ababa.

[5] Tadesse, N., et al. (2013) High Prevalence of HIV/AIDS Risky Sexual Behaviors 
among Street Youth in Gondar Town. BMC Research Notes, 6, 234.

https://doi.org/10.1186/1756-0500-6-234

[6] PEPFAR (2012) Operational Plan Report, Ethiopia Addis Ababa.

[7] Ethiopia FDRE (2014) Country Progress Report on the HIV Response.

[8] Harms, S., et al. (2010) The Orphaning Experience: Descriptions from Ugandan Youth Who Have Lost Parents to HIV/AIDS. Child and Adolescent Psychiatry and Mental Health, 4, 6. https://doi.org/10.1186/1753-2000-4-6

[9] Tadele, G. (2009) "Unrecognized Victims": Sexual Abuse against Male Street Children in Merkato Area, Addis Ababa. The Ethiopian Journal of Health Development, 23, 174-182.

[10] Mathiti, V. (2008) The Quality of Life of Street Children Accommodated at Three Shelters in Pretoria: An Exploratory Study. Journal of Early Child Development and Care, 176, 253-269. https://doi.org/10.1080/03004430500258289

[11] Murray, L.K., et al. (2012) A Qualitative Study of Georgian Youth Who Are on the Street or Institutionalized. International Journal of Pediatrics, 2012, Article ID: 921604, $11 \mathrm{p}$.

[12] Kayembe, P.K., Mapatano, M.A., Fatuma, A.B., et al. (2008) Knowledge of HIV, Sexual Behavior and Correlates of Risky Sex among Street Children in Kinshasa, Democratic Republic of Congo. East African Journal of Public Health, 5, 186-192.

[13] Nada, K.H. and Suliman, El D.A. (2010) Violence, Abuse, Alcohol and Drug Use, and Sexual Behaviors in Street Children of Greater. Cairo and Alexandria, Egypt. AIDS, 24, S39-S44. https://doi.org/10.1097/01.aids.0000386732.02425.d1

[14] Busza, J., Balakireva, O.M., Teltschik, A., et al. (2011) Street-Based Adolescents at High Risk of HIV in Ukraine. Journal of Epidemiology and Community Health, 65, 1166-1170. https://doi.org/10.1136/jech.2009.097469

[15] Mudingayi, A., et al. (2011) HIV Knowledge and Sexual Risk Behavior among Street Adolescents in Rehabilitation Centres in Kinshasa; DRC: Gender Differences. Pan African Medical Journal, 10, 23. https://doi.org/10.4314/pamj.v10i0.72233

[16] Brhane, T., Assefa, B. and Birhan, N. (2014) Reproductive Health Behaviour of Street Youth and Associated Factors in Gondar City, Northwest Ethiopia. International Journal of Medicine and Biomedical Research, 3, 28-37.

[17] Karmacharya, D., et al. (2012) A Study of the Prevalence and Risk Factors Leading to HIV Infection among a Sample of Street Children and Youth of Kathmandu. AIDS Research and Therapy. AIDS Research and Therapy, 9, 25. https://doi.org/10.1186/1742-6405-9-25

[18] Embleton, L., et al. (2012) Knowledge, Attitudes, and Substance Use Practices among Street Children in Western Kenya. Substance Use \& Misuse, 47, 1234-1247. https://doi.org/10.3109/10826084.2012.700678

[19] Habtamu, D. and Adamu, A. (2013) Assessment of Sexual and Reproductive Health Status of Street Children in Addis Ababa. Journal of Sexually Transmitted Diseases, 2013, Article ID: 524076, 20 p.

[20] Sorber, R., Winston, S., Koech, J., et al. (2014) Social and Economic Characteristics of Street Youth by Gender and Level of Street Involvement in Eldoret, Kenya. PLoS ONE, 9, e97587. https://doi.org/10.1371/journal.pone.0097587

[21] Ntaganira, J., Hosner, S., Brown, L. and Mock, N.B. (2012) Sexual Risk Behaviors among Youth Heads of Household in Gikongoro, South Province of Rwanda. BMC Public Health, 12, 225. https://doi.org/10.1186/1471-2458-12-225 
Submit or recommend next manuscript to SCIRP and we will provide best service for you:

Accepting pre-submission inquiries through Email, Facebook, LinkedIn, Twitter, etc. A wide selection of journals (inclusive of 9 subjects, more than 200 journals)

Providing 24-hour high-quality service

User-friendly online submission system

Fair and swift peer-review system

Efficient typesetting and proofreading procedure

Display of the result of downloads and visits, as well as the number of cited articles Maximum dissemination of your research work

Submit your manuscript at: http://papersubmission.scirp.org/

Or contact wja@scirp.org 